\title{
Problems, Challenges and Prospects of Indonesian Muslim Community in Sydney for Promoting Tolerance
}

\author{
Ahmad Muttaqin ${ }^{1}$, Achmad Zainal Arifin ${ }^{2}$, Firdaus Wajdi $^{1}$ \\ ${ }^{1}$ Western Sydney University \\ ${ }^{2}$ UIN Sunan Kalijaga Yogyakarta
}

DOI: http://dx.doi.org/10.15294/komunitas.v8i2.5971

Received : 11 January 2016; Accepted: 19 August 2016; Published: September 2016

\begin{abstract}
This paper elucidates a map of Indonesian Muslim communities around Sydney in order to observe the possibility to promote a moderate and tolerant Indonesian Islam worldwide. Indonesian Muslims who live in Australia are relatively small if we consider that we are the closer neighbor of Australia and have the biggest Muslim populations in the world. Most Indonesian Muslim communities in Sydney are in a form of kelompok pengajian (Islamic study group), which is commonly based on ethnicity, regionalism (province and regency), and religious affiliation with Indonesian Islamic groups. The main problems of Indonesian Muslim communities in Sydney are an ambiguous identity, laziness for integration, and dream to home country. Most Indonesian Muslim diaspora in Sydney only consider Australia as the land for making money. Therefore, their inclusion to Australian community is just being "Indonesian Muslim in Australia" and it seems hard for them to be "Australian Muslim", especially in the case of those who already changed to be Australian citizens. This kind of diaspora attitude differs from Muslims Diasporas from the Middle East and South Asia countries who are mostly ready to be fully Australian Muslim. Naturally, most Indonesian Muslim communities put their emphasis to develop their community based on social needs and try to avoid political idea of Islamism. In this case, the Indonesian government, through the Indonesian Consulate in Sydney, has great resources to promote moderate and tolerant views of Indonesian Islam to other Muslim communities, as well as to Western media.
\end{abstract}

Keywords: Indonesian Muslim; diaspora; identity; tolerance

\section{INTRODUCTION}

Islam in Australia has a long historical process. Islam had been known before the Western people settled in Australia. It can be traced back around 1650 with the coming of Macassan fishermen along the northern coast of Australia (Kabir 2004). However, most Muslims in Australia today are first or second generation immigrants. Most of them have arrived under the humanitarian component of the permanent immigration intake as refugees, while others have arrived as permanent immigrants under the skilled and family reunion programs(Akbarzadeh \& Yasmeen 2005; Burnley 2001; Stephenson

\footnotetext{
$\triangle$ Corresponding author :

Address: Prodi Studi Agama-agama, Fakultas Ushuluddin \& Pemikiran Islam, UIN Sunan Kalijaga, Yogyakarta J1. Adisucipto Yogyakarta, Indonesia

Email : ${ }^{1}$ ahmad.muttaqin@uin-suka.ac.id, achmad 2arifin@uin-suka.ac.id, ${ }^{3}$ firdaus_wajdi@yahoo.co.id
}

2010). Muslim communities in Australia include immigrants and their Australian-born families from the Middle East - including Lebanon - Indonesia, Turkey, Malaysia, the Indian sub-continent and Africa. Currently, a growing number of Indigenous Australians are converting to the Muslim faith, as are Australians of Anglo-Celtic background.

Oliver Roy asserts that the first generation of Muslim migrants arrived in the West in a pristine 'ethnic culture' without any experience in adapting their religious practices and traditions with a new and relatively un-Islamic environment (Roy 2004). Searching a new identity then becomes a p-ISSN 2086 - 5465 | e-ISSN 2460-7320

UNNDS JDURNALS


major theme for the second generation of Muslims in the West, including in Australia. In this case, the issue of ethnicity seems to be more attractive for Australian researchers in discussing Islam. Several studies indicate that ethnic background of immigrants has significant impact on the ways they perceive and practice Islam (Dreher, \& Ho 2009; Hage 2002; Kabir 2004). Kabir, for example, shows that the problem of Muslim has a strong relationship with race relation. Collins even indicates that Lebanese migrants, especially the youth, suffered from stereotyping as trouble makers within society (Collins 2000; Dragojlovic, 2012; French 2008; Heiss 2010). Australian Muslims in general are also accused for their unwillingness to integrate with the wider society. The pride of Islam and national origin are seen as two major factors, which obstruct some inclusion programs both initiated by the Australian government and other local institutions (Akbarzadeh \& Yasmeen 2005).

Despite these complex relationships between Islam and ethnicity, which tend to produce uncomfort situation, these two aspects can actually be used as a source of building Islamic social capital for Indonesian Muslim communities in Sydney. As described by Bourdieu, social capital means'the aggregate of actual or potential resources which are linked to the possession of adurable network'(Bourdieu 1986, p.248; Slama 2011; Van Bruinessen 2012; Winamita 2012). This definition implies that assets for building social capital can be material, such as resources and services, or non-material, such as support or prestige. Another social capital theorist, Roebert Putnam, has different perspective in defining social capital, which sees it as 'social networks and the associated norms of reciprocity and trustworthiness' (Putnam 2000, 2007; Howell 2005; Poynting 2006). It is clear that Putnam focuses on the normsand values which he suggests underpin effective networks, such as trust and civic participation. Although both theorists do not included specifically on religious aspect, but we can clearly see that religious community also offers a dimension of social support and networks of relationship. The- refore, in this research, Muslim communities are seen as forums for developing social connections and as forums through which values and norms are transmitted.

Farooqi(2006) demonstrates how these two aspects, developing social connection and transmitting values and norms, can be used to explore factors which drive network formation in relation to Muslim community development. He further asserts that 'Islamic social capital is the networking that helps to create the linkages, which in turn motivate people to follow up the Islamic conventions and norms' such as the ideas of 'social well-being,' 'brotherhood,' 'socioeconomic justice, and the 'continued development of human potential' (2006 p.114). In this way, Farooqi's understanding of 'Islamic social capital' encapsulates both Putnam and Bourdieu'sunderstandings of social capital. Based on Farooqi's formulation on 'Islamic social capital,' this research will identify certain assets of Indonesian Muslim communities in Sydney and closely observe various forms of relationships among them, as well as with other Muslim communities in Sydney area.

\section{Islam and Muslim in Australia}

The most common sources explaining the first encounter between Australian people and Muslims claim that Islam was brought to Australia by the Afghan cameleers in 1860 . However, Regina Ganter through her study at the Northern area of Australia, particularly on the northern shores of Arnhem Land, and Kayu Java, the beaches on the Kimberley coast and the off-shore islands of the Arafura Sea, revealed that since 1750 , the Muslims from Makassar (the Sultanate of Gowa in South Sulawesi) had regular visit to that place for collecting trepang or sea cucumber (Ganter, Martinez, \& Lee 2006). These regular visits had profoundly impacted on some languages and cultures or traditions, such as circumcision, which is widely practiced by the aborigines(Akbarzadeh \& Saeed 2001). For some Australians, including the government, this predating time of the Whites in Australia seems hard to be acknowledged because of the political reasons and to pre- 
serve the class domination of the White upon the Muslims. Therefore, the first view of the coming of Islam in Australia is more popular than the second one.

However, there is also interesting reason provided by the Australian government in supporting this first view. During the highest season of camel transport industry, there were around 3000 Muslims from Afghan who worked for crafting water and goods in the difficult terrain. Most of these camel drivers are believed to be the first who build a Muslim community in Australia. With the end of camel transport industry in 1920s, followed by the restrictive of White Australian Immigrant policy, started in 1901, the numbers of Afghan ideclined (Akbarzadeh \& Saeed 2001). It was not until the end of 1960 shen the White Australia immigration policy was dismantled, the numbers of Muslims in Australia resumed. The number of Muslims had grown rapidly, especially during the post-war period. As a result, Muslims immigrants, particularly those who came from Turkey and Lebanon, started to settle and built some Muslim communities. Most of these Muslim immigrants built their community around the industrial cities, especially in Sydney and Melbourne.

Beside these two countries, Turkey and Lebanon, Muslim immigrants are mostly come from the members of Commonwealth countries, such as: India, Pakistan, Bangladesh, and Fiji; and also from conflicting countries, such as Bosnia, Afghanistan, and some Middle Eastern countries. Based on census in 2011, the number of Muslim in Australia has reached 476.290 . This number increases $39.9 \%$ from the 2006 census, see the Table 1.

Although the total Muslims in Australia only represents $2.2 \%$ of total population in Australia, some Muslim leaders claim that the actual number of Muslims in Australia can be doubled because there are many Muslims who do not want to state their religious identity (as Muslims) because of security reasons, such as worrying upon some discriminative treatments or loosing opportunity to get certain jobs. Based on above data, Islam becomes the second fastest growing religion in Australia after Hinduism. Interestingly, the number of Muslims, which was dominated by immigrants, tends to change gradually to born-Australian Muslims. In this case, $37.6 \%$ of Muslim population in Australia are born in this continent, as it shows in the Table 2.

The high number of Muslims who born in Australia has created a great opportunity for Muslims to soften or even eliminate a negative opinion imposed by the White Australians that Muslims are reluctant to integrate with the wider society. Muslim communities, to some extent, are commonly seen by the White Australian as exclusive groups (Akbarzadeh \& Saeed 2001; Saeed 2003).

Table 1. Religions in the 2011 Census

\begin{tabular}{lrrrr}
\hline \multirow{2}{*}{ Religion } & \multicolumn{2}{c}{ 2011 } & \multicolumn{3}{c}{ Change 2006-2011 } \\
\cline { 2 - 5 } & \multicolumn{1}{c}{ Number } & \multicolumn{1}{c}{$\%$} & Number & \multicolumn{1}{c}{$\%$} \\
\hline Christianity & 13.150 .670 & 61.1 & 464.842 & 3.7 \\
Buddhism & 528.977 & 2.5 & 110.219 & 26.3 \\
Islam & 476.290 & 2.2 & 135.898 & 39.9 \\
Hinduism & 275.535 & 1.3 & 127.411 & 86.0 \\
Judaism & 97.336 & 0.5 & 8.506 & 9.6 \\
Other religions & 168.196 & 0.8 & 59.170 & 54.3 \\
No religion & 4.796 .786 & 22.3 & 1.090 .233 & 29.4 \\
Not stated & 1.839 .649 & 8.6 & 384.308 & -17.3 \\
Supplementary codes & 174.280 & 0.8 & 40.461 & 30.2 \\
\hline Total & 21.507 .719 & & 1.652 .432 & 8.3 \\
\hline Source: Adapted
\end{tabular}

Source: Adapted from Hassan (2015) 
Table 2. Country of birth of Muslim population: top 15 source countries 2011

\begin{tabular}{lrr}
\hline \multicolumn{1}{c}{ Country of birth } & Muslims & $\begin{array}{c}\text { \% of Muslim } \\
\text { population }\end{array}$ \\
\hline Australia & 179.080 & 37.6 \\
Lebanon & 33.560 & 7.0 \\
Pakistan & 26.466 & 5.6 \\
Afghanistan & 26.043 & 5.5 \\
Turkey & 25.311 & 5.3 \\
Bangladesh & 23.665 & 5.0 \\
Iraq & 15.395 & 3.2 \\
Iran & 12.686 & 2.7 \\
Indonesia & 12.240 & 2.6 \\
India & 10.125 & 2.1 \\
Saudi Arabia & 8.709 & 1.8 \\
Bosnia \& Herzegovina & 7.603 & 1.6 \\
Malaysia & 7.225 & 1.5 \\
Fiji & 7.191 & 1.5 \\
Somalia & 5.424 & 1.1 \\
\hline Source: Adapted from Hasan $(2015)$. &
\end{tabular}

Source: Adapted from Hasan (2015).

Beside this potential opportunity to be more integrated to the wider society, the elder generation of immigrant Muslim are still facing some problems related to their ethnicity. First, there are still some Muslim immigrants who have not enough ability of speaking in English. According to the census in 2006 and 2011, there is no significant development in the number of Muslims who has no or poor in English proficiency (Hassan 2015). Both censuses reported around 15 per cent of Muslims included in this category. This number is even smaller when it comes to the daily usage of English in the family. The use of English in everyday life of Muslim communities is also reflected from the language being used in Mosque, especially for Friday sermon. Many mosques are still heavily associated with ethnicity or country-origin of the Muslim communities, such as: Turkey Mosque, Lebanese Mosque, or Bosnian Mosque, which use Turkish, Arabic, and Bosnian respectively(Kabir 2004).

Second, as a consequence of the first problem, those who do not have good English skill tend to have a more complicated problem of identity. The opinion that some Muslim communities are exclusive, to some extent, could not be separated from the fact that some Muslims are having difficulties in expressing and presenting themselves in front of others. Lower percentage of using English in their family and their tendency to stay at the same region has also contributed in creating an exclusive image to others. Actually, the language barrier is not only faced by Muslims, but it is also experienced by other religious groups, particularly those who build their holy prayer based on ethnicity. However, since Islam is the second fastest growing religion in the country and there is also growing number of radicalism across Islamic world, including in Australia, in the last two decades, more attention is paid toward Islamic communities.

Regarding the issue of identity, the fundamental questions for Muslims in Australia to be answered is whether they will put nationality or being Australian before their religion or being Muslims. Although the overwhelming Muslims strongly agree in responding a statement that they can be a good Muslim and a good Australian (Akbarzadeh \& Yasmeen 2005), the suspicion toward Muslim communities across the country is still prevalent. According to Ustadz Emil, an Indonesian Muslim who work for Dompet Dhuafa, as well as a teacher of 
Islamic studies in some Indonesian communities in Sydney, to overcome this suspicion, Muslims need to be more involved in public services and events. They also need to invite others to come and attend various activities conducted in their mosques (Personal Interview, 25 November 2015). In fact, some mosques already did these activities and become more open toward anyone who wants to know more about Islam and Muslim communities.

The problem of identity, which is mostly based on ethnicity, eventually will be wiped away if we rely on statistical data. The growing significant number of Muslim born in Australia, which tells us the higher percentage of Muslim populations, will create a better environment to develop and cooperate with the wider society. Overall, this identity problem should create awareness among the Australians that Muslims are not only associated with Arab and some Middle Eastern countries, which is only made up of 42 per cent of the Muslims in Australia (Hassan 2015; Underabi 2014). There are no single ethnics or Islamic streams that could claim as the only representative of Australian Muslim. The younger generation of Muslim, to some extent, will have a greater chance to do this.

\section{Muslim Communities in Sydney}

Similar to other places across the country, Muslims in New South Wales are also culturally and linguistically diverse groups. However, according to Jan Ali, lecturer and researcher at Centre of Study for Muslim and Society (CSMS), Western Sydney University,Muslims in New South Wales are considered as the most heterogeneous in ethnicities or country-origins, languages, and even religious or Islamic group's affiliations" (Personal Interview, 27 November 2015). The diversity ofc ultures, languages, and religious affiliations can be a potential source for building various Muslim communities. However, in some cases, it can also be a source for conflict among Muslim communities. These diversities can easily be seen from the establishment of various different worship places, which can be mosques or mushala (smaller mosque not for conducting Friday prayer). When the religious affiliation is stronger than other factors in certain Muslim communities, they will only have a Sunni or Shi'i mosque. Meanwhile, when the ethnic factors become a more dominant, Muslim communities may have Turkish Sunni Mosque, Lebanese Shi'i Mosque, Bosnian Sunni Mosque, and so forth. Therefore, the need of Muslim communities in building mosques is relatively high in Sydney.

According to Underabi (2014), there are 167 Islamic places of worship, both mosques and mushala, across New South Wales. Most of these Islamic places of worships are concentrated in the Western Sydney regions, especially in two city councils where the percentage of Muslim population are much higher than the national average: Auburn and Bankstown. Based on 2011 Australian census, it is reported that the percentage number of Muslims in Bankstown is $19.1 \%$, the second largest religious affiliation after Catholicism. Meanwhile, in $\mathrm{Au}-$ burn, the numbers of Muslims even become the highest, with the percentage of $23.6 \%$ from the total population of the Auburn city-council.The growth of mosques in New South Wales is very high. Around $64 \%$ of mosques were built within the last two decades, especially in these two city councils. These relatively new mosques indicate that the needs to build a new mosque is not merely based on religious orientation, but also on the need of developing community based on ethnicity. This can be clearly seen from the language used in the mosque, especially on the daily activities. It is also very common among Australian Muslims to name certain mosque with ethnic identity, such as Turkish Mosque or Lebanese Mosque, instead of Sunni or Shi'i Mosque, although the mosques have Arabic names, such as al-Hijrah Mosque, Abu Bakr Mosque, and so forth.

Within the Western Sydney regions, the role of educational institution, especially Western Sydney University, the former University of Western Sydney, is crucial in promoting Islam to a wider society. Regular meetings, such as public lecture, seminar, 
and Islamic book fair, are open for everyone, not only limited to the students. Besides, the Western Sydney University, through its Centre of Study for Religion and Society, also held a regular meeting for imams of mosques in Western Sydney regions (Personal Interview with Adam Possamai, the Director of CSRS, 26 November 2015). Most imams appreciated the initiative of the campus to facilitate them for having regular meetings to discuss various issues that have been facing by Muslim communities in New South Wales. One thing that should be noted related to the existence of Imams in New South Wales is their average of age and country-origin. Around $47 \%$ of imams are relatively young as they are aged below 40. Only $24 \%$ of imams are aged more than 60 (Underabi 2014, p.42). Most of the imams also have a very good qualification in Islamic Studies. They graduated from some famous university with a good Islamic Studies program, such as: Madinah University in Saudi Arabia or Al-Azhar University in Egypt for Sunni imams; and from Qom for Shi'i imams.

Although imam is not the only person in directing and shaping the religiosity of Muslim community's members, he undeniably play significant role in developing community through most activities held in the mosque. The existence of relatively young and Australian-born imams has created an opportunity for Muslim communities around Sydney to be more open to wider audiences, including to White Australian. Mixed ethnicities existed in several activities in the mosques have become more common today. This is a better situation for Muslim community compared to two or three decades before when each Muslim community, based on their ethnic or country-origin, tended to invite their imam from their own countries. Some of these "imported" imams even have no ability to speak in English. Therefore, the language used in their mosque was also same with the language used in their country's origin. This situation, to some extent, has created difficulties for Muslim community to develop and adapt with its wider society.
These differences in culture, language, and religious orientation, can also be a great potential for Muslim in New South Wales to soften the negative image that has been created by Western media because of radicalism and terrorism. The diversity of Muslim communities offers different picture of Islam and Muslim community in more fair ways. The richness of traditions, brought by Muslims immigrants from all of the worlds, can be excellent tools for promoting Islam as a peaceful religion. In some places around the Western Sydney regions, Islamic festival has become an annual agenda of the city council. Different traditions from all Muslim communities at the city council region are exposed through street parade or being showed on the stages. Lakemba Festivals, Muslim Cultural Weeks, and Bankstown Festivals, are examples of annual events held in the Canterbury and Bankstown city council.

Beside those cultural and language differences, various streams of Islam have also shaped the characteristics of Muslim communities across New South Wales, especially around the metropolis city of Sydney. General picture of Islamic groups, which is commonly only divided into two: Sunni and Shi'i, seems to be noted more carefully. Both Sunni and Shi'i in the context of Sydney have various streams represented through the affiliation of the mosques. Heterogeneity of Sunni, for example, needs to be taken into account because there are some fundamental differences among them, especially after the rise of transnational Islam (Meuleman 2002; Saeed 2003). However, unlike in Christianity, where people with different denomination will likely to go to different churches, in Islam those who have some fundamental differences are still allowed to worship in the same mosque. For Muslim, all mosques belong to God. So, any Muslims can go to any mosque they wanted.

In general, apart from the tensions among Muslim communities, the growth of Muslims in New South Wales, especially in the Western Sydney regions, indicates that many Muslim immigrants are still attracted to come and live in Sydney. The composition 
of Muslim population, which is dominated by younger people, has a great potential, not only to develop Muslim communities, but also to boost the Sydney's economics growth. Furthermore, the main reason for most Muslims migrated to Australia and chose to live in Sydney is to seek a better economics and social life, including most Muslims from Indonesia. Those are among the most significant Muslim communities in Sydney. They have settled and integrated with other communities and make a mutual relationship, especially through sharing place of worship (mosque or mushala), Halal Food Businesses, and marriages.

\section{Sharing Place of Worship}

The pattern of worship of the Muslim communities in Sydney is moderately based on their origin background. Although it is not exclusive, they tend to pray and study the Quran along with their same origin background. During our observation in Sydney, especially in two city councils where the percentage of Muslims are higher than the national average, it is quite easy to determine which mosques belong to particular Muslim community. For example, in Lakemba, a Bankstown area of NSW, there is Lakemba Mosque (also known as Masjid Ali Bin AbiTaleb). This big mosque although mainly used by Lebanese, as there are significant Lebanese Muslim around the area of Bankstown and Canterbury, it also place for others Muslims such as Pakistani, Bangladeshi, Somali and South-East Asian backgrounds. Interestingly, in some cases, each country origins of those Muslims has their different schedule in using the mosque other than the daily prayers. This shows that each Muslim community still has a strong attachment with their ethnicities.

In the area of Lakemba, there are also Bangladeshi mosque. In this mosque, before the Friday prayers is conducted, there are sermons delivered in Banglaand then followed by the Friday prayers in Arabic. Mostly, the jamaah of the mosque are the Bangla Muslims who live around the area of Lakemba and Wiley Park. But, other Muslims are also welcome, including the Indonesian
Muslims who also share the living area in Lakemba-Bankstown.

A bit further north, in the area of Auburn, there is a Turkish big mosque knows as Gallipoli mosque. The ornament both exterior and interior of this mosque will remind the visitors to the mosque in Turkey. This mosque is located in the heart of Turkish Muslim community in Auburn. The sermons are mostly delivered in Turkish, although not all Muslims there understand Turkish, even for young generation of the Turk. The use of Turkish, undoubtedly, is related to the existence of some older generation of the Turks who still have no English ability. Besides, it is also a part of romanticism, in the sense that they want to bring nuances of their home country into their new home in Sydney. To accommodate the needs of Muslims from other countries, the imam added a short English translation during their sermons.

In general, the Muslims perform their religious rituals in the religious institution belong to their ethnical background, although it is never restricted to other Muslim communities to participate. With this no restriction nature of the mosque then the interaction between the communities can take place. For example, logically, the Muslim community will find the nearest place of worship with regard to where they live or work. This is a quite common phenomenon. During Friday prayer, some Indonesian Muslims join the large Lebanese mosque in Lakemba. While, on the other hand, some Muslim with South Asian origin prefer to pray at Indonesian musholla at Iqro during juma or daily prayers.

\section{Halal Food Business}

Other than the religious ritual, Muslims in Sydney, who live in relatively same shared area of Bankstown and Canterbury, as well as Auburn councils, also use local businesses as place for building networks among them. What we mean by this is that some Muslims provide groceries and other needs, such as halal meats and so forth. The need of Muslims upon halal foods, which are rarely available in general shops operated by 


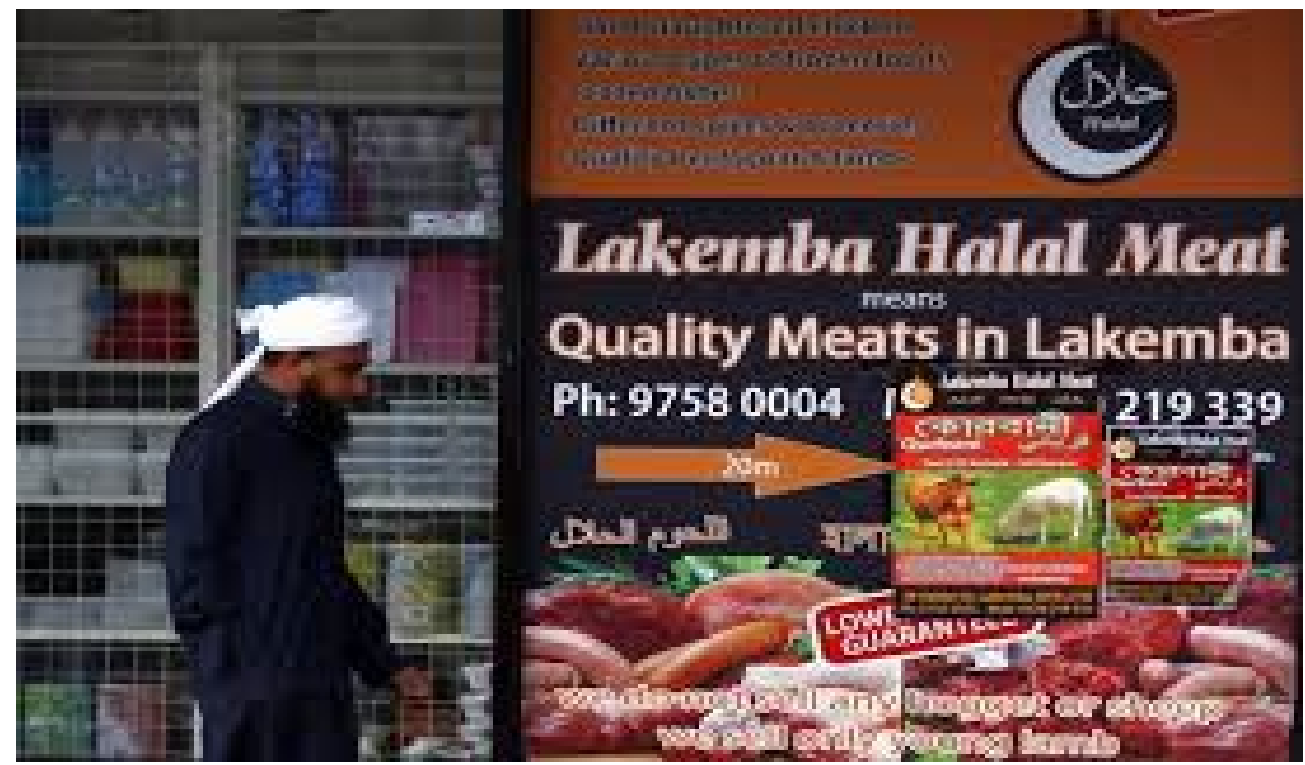

Figure 1: One of halal meat shop in Lakemba

non-Muslims, have created an opportunity for some Muslims to open shops and groceries with specialty on providing halal products. For most Muslims in Sydney, as described by Ustad Wahyu, they prefer to shop in groceries or restaurants that belong to fellow Muslims rather than in regular shops or supermarket. "It is more confortable for us to shop in Muslim's groceries because we do not need to look for halal certification or doubt with any products sell in those groceries (Personal Interview, 29 November 2015). This situation has created a great opportunity among Muslims for different ethnicities to interact and build networks. In most Muslim's shops, there is always a special place to put pamphlets, flyers and other letters to inform various religious activities for local Muslims.

The market for halal food has also changed the attitude of business, particularly in the common area of Muslims. Not only does the small food shop in most food courts, both some big franchise, such as KFC provide halal meat within their menu. Most if not all food stall in Bankstown Centro food-court also provide certified halal foods. The need of Muslims in buying Halal foods and meats can be an entry point to build more relationship among Muslims in Sydney. In these places, Muslims from various country-origins meet and build a so- cial networking among Muslims. This can clearly be seen that in many halal foods or meats shops there are always many pamphlets, announcements, invitations to attend mosque's activities, and so forth.

\section{Marriage}

Marriage is also a significant feature of interaction among Muslims in Sydney. Although this might less significant compared to other forms, but this take place among Muslims in Sydney. One of our friends, a convert Australian Males student at Western Sydney University acknowledged that he married to Indonesian female Muslim. This is due to his new religion which allowed only marrying someone in the same religions. Inter-race marriage becomes recent phenomenon and more frequent for younger Muslims (Personal Interview with Sulaiman, 24 November 2015). This phenomenon is in line with the decrease of the practice of arranged marriage for Muslim family. Only few Muslim family still practice this arranged marriage, especially when it is contrasted to the culture of Australian, which tend to give freedom for those who passed 18 years-old.

Muslim families that are still practicing the tradition of arranged marriage usually comes from wealthy family for various reasons, ranging from economics, social status, to religious expertise. Inter-race 
marriage among Muslims has created some advantages for Muslim communities. It can be one of ways to understand the different cultures among Muslims and minimize tensions among them that often be based on different traditions among Muslims, especially when it comes to different forms of worships. The segmentation among Muslim communities in Sydney will automatically decrease as the inter-race marriage among Muslims becomes more popular.

Those three ways in building relationships among Muslims in Sydney are still apparent and become the most easiest and populous ways to be practiced, especially within the two city councils, Bankstown and Auburn. However, in the case of new comers, especially students, the second way, which is using halal shops, becomes the most attractive one to find many valuable information on local Muslim activities. The need of Muslims to get halal products for their everyday life becomes the most common reason why Muslim shops and groceries are important to examine the social interactions among the Muslims. In many cases, as described by Ustad Wahyu who live on the upper level of Indonesian Muslim shop, "many Indonesian students got the first information and eventually joint with certain Indonesian Muslim groups from this shop and it is also the case with other Muslim communities, especially Bangladeshi, Indian, or Pakistani” (Personal Interview, 28 November 2015).

\section{Indonesian Muslim Communities in Sydney: Problems, Challenges and Pros- pects}

When discussing the problematic position and relation between Muslims diaspora in the West and the secular state, Bryan S. Turner in his introductory paragraph wrote as follow:

\footnotetext{
"Many Muslims now live in secular societies that promote cultural assimilation as the long-term objective of the "ethnic mosaic." As a result, for Muslims, the principal challenge of the new global environment is how to sustain an Islamic identity in the context of modernization
}

and assimilation in liberal multicultural regimes(Turner 2013 p.255)."

Turner also listed four problems of incorporating Islam into the modern Western polity: "(1) Islam does not recognize the separation of Church and state; (2) Islam has no "Church" as such; (3) Islamic law (Shari'a) is not merely a law of private status; (4) the Islamic community (ummah) is a transnational social system. From the perspective of Western liberalism, Islam does not fit the Wesphalian model of individual conscience and public tolerance (Turner 2013, p.256)." Turner further asserts that "due to the process of separation of the state and church as well as it's political and social change in the West, Islam has been identified as an aspect of modern problem of state security(Turner 2013, p.257)."

Indonesian Muslims communities in Sydney are part of Muslims minority in the Western liberal society that to some extent face the above problem as described by Turner. To understand comprehensive picture of their problems, challenges and prospects, first of all, this section will delineate both internal and external problems. Special attention will be paid to the issues of identity on being minority in Western society, socially narrow, the dream for returning to their home country, segmentation and the challenge of trans-national Islamic movements. After discussing the problems and challenges, this section will examine prospect and opportunity of Indonesian Muslims communities in Sydney to promote moderate and tolerance values of Islam in Australia.

\section{Glimpse of Indonesian Muslim Com- munity in Sydney}

According to KJRI Sydney, the Indonesian community in Australia has developed and grown into various different community. They can be distinguished into five big categories: (1) general community, such as Indonesian diaspora network, Indonesian Community Council (NSW), Perhimpunan Masyarakat Indonesia dan Perhimpunan Indonesia; (2) Indonesian groups based on their ethnicity, such as Minangsaiyo, Jawa 
Timuran, Isamic Sundanese Association (ISA) of NSW; (3) based on religion such as Centre for Islamic Development and Education (CIDE), IQRO foundation, and Ashabul Kahfi (Language School). (4) IndonesianAsutralian Joint Community such as Sanggar Srikandi Indonesia, Australia-Indonesia Art Alliance, Kelompok Kontemporer Garis (Gabungan Artis Australia Indonesia; and (5) Education and Culture such as Australia Indonesia Institute (AII).

The above categories and examples are not final. For sure, there are many other organizations that accommodate Indonesian society in Sydney or even bigger in Australia. However, this report mainly focuses on organization based on religion, especially the Indonesian Muslim community in Sydney. This can clearly be seen from various different backgrounds that made up many Indonesian Muslim groups as mentioned in the table below.

According to our informants there are more than 30 Indonesian Muslim associations, most of them in the form of majelis taklim or kelompok pengajian. Some of tho- se can be seen from the list below:

There are, of course, other Indonesian Muslim Communities that are not in the list above. It is actually not as easy as we might think to trace back all Indonesian Muslim Communities, especially there are some of them that are exclusive only for certain people, such as those pengajian based on mixed Indonesian-Australian families or also on some hardliner groups. From above list, it is clear that Indonesian Muslim communities are formed based on several reasons: ethnicity, regional (province or regency in Indonesia), Indonesian Islamic organizations, and transnational Islamic groups. Interestingly, it is common that many Indonesian Muslims' families become members of more than two organizations. This situationhas created a unique interaction among Indonesian Muslim communities.

\section{Ambiguous Identity, Laziness Integra- tion and Dream to Home Country} Compared to their counterpart from Middle East and South Asia, Indonesian Muslim in Sydney is relatively small in number. In

Table 3. Indonesia Muslim Group

\begin{tabular}{llll}
\hline NO & Group Names & NO & Group Names \\
\hline 1 & Ashabul Kahfi & 18. & Ikatadas \\
2 & Acheh Australian Society & 19. & IKPPS \\
3 & Al Amin & 20. & Jamaah Pengajian Illawarra (Wollongong) \\
4 & Al Muhajirin & 21. & Kajian Tematik Muslimah (Kamus) \\
5 & Al Ikhlash (Al Ikhlas - Australian Indone- & 22. & Kerukunan Keluarga Sulawesi Selatan \\
& sian Muslim Cultural Centre, Inc) & & \\
6 & Al Irsyad & 23. & Istiqomah \\
7 & As Salam & 24. & Arek-arek Jawa Timur \\
8 & Babussalam Riau Community & 25. & MT Raudhatul Ilmi \\
9 & Cahaya Islam Australia & 26. & Muhammadiyah ranting NSW \\
10 & Islamic Society of Manly Warringah (Dee & 27. & Minang Saiyo Sydney \\
& Why) & & \\
11 & Fajar Islam & 28. & Samara \\
12 & Forum Pengajian Jumat (Sydney Western & 29. & Pengajian Usyd \\
& Suburb) & & \\
13 & FORSIC & 30. & KPII UNSW \\
14 & Ibu-Ibu Soleha Al Hijrah & 31. & Pengajian UTS \\
15 & Pengajian Ibu-ibu Sabtu Pagi & 32. & Pengajian Macquarie Uni \\
16 & Indonesian Islamic Association (IIA) & 33. & Pengajian UWS \\
17 & Ikapabasko & 34. & Tahsin Ahad Pagi (Iqro Foundation) \\
\hline
\end{tabular}

Source: Adapted from various informants, especially from Muhammad Nur, the President of Iqra' Foundation, 24 November 2015. 
theory, small groups tend to have less social resonation than those the bigger one. The question therefore, how significant is Indonesian Muslim in Sydney contributing to the integration process of Muslims in Australia into Australian society? The question is based on the fact that "Anti-Muslim rhetoric has unfairly identified Islamic values as in opposition of Australian values,"(Giles 2010, p.164) implying there is a big barrier for Muslim to integrate in the Australian culture.

One of the problems behind the barrier of integration is the ambiguity of Muslim identity in Australia. Most of Muslim identities in Australia are still ambiguous, whether they are just Muslim in Australia or Muslim of Australia, or Australian Muslim? (Akbarzadeh \& Saeed 2001; Parekh 2005). Since the inclusion and sense of belonging is an important value for a cohesive society, so it is important to discern the sense of belonging to Australian society among Indonesian Muslims in Sydney. Following Bikkhu Parekh observation on Muslim in Europe,the question to Indonesian Muslim in Sydney is how do they identify themselves in Australia? Do they, even those who have already got green card, prefer identifying themselves as just "Indonesian Muslim in Australia," or "Indonesian Muslim of Australia", or "Australian Muslim from Indonesia"?

Compared to Muslim communities from other countries, it seems to us that Indonesian Muslim communities in Sydney tend to be lazy to actively participate in the process of integration. In 2011, for example, we visit a Lakemba Multicultural Festival, where many communities from various nationality and cultural backgrounds show off their foods, attires, and arts in stalls and stages. We did not see any single representatives from Indonesian Muslim communities that participate in the festival (Parekh, 2005, p.200). The same case also happened in Muslim Student Association (MSA) in a number of Universities. It was hard to find Indonesian Muslim students who are proactively involved as committee board of the MSA. Most Indonesian Muslim students seem enjoyed to be just participants, ja- maah, or even observers.

No matter how long Indonesian Muslims have lived in Sydney, they keep their dream for returning to home country, someday. Although they already have house, children who are raised in Australia, the desire to back to home country are still common. Many Indonesian prefer to choose as Permanent Residence rather than being an Australian citizen. In a case when some advantages for being a permanent resident are being cut, typically the husband of the family will take an Australian citizenship, while the wife is still hold Indonesian citizenship to guarantee that they will still have access to return to Indonesia someday. Therefore, they tend to invest their Australian income in land, property and even business in Indonesia as preparation for their pension.

While Indonesian Muslim student who took master or doctoral program in Australia are proudly sending their children to Australian public schools, Indonesian Muslims permanent resident family prefer to send their children to Indonesia pesantren for their junior and senior high school. One of the common reasons to send their kids to Indonesian school is to protect them from Australian social life, which they regard as has been polluted by liberal values (Personal Interview with Ustad Wahyu, 28 November 2015).

Another effort to protect their family from the pollution of western liberal social life, most Indonesian Muslim families in Sydney are not hesitate to do some kind of "arranged married" for their kids. As among the goal for family gathering is to introduce their family members to their relative, it is a common trend a mother who has a young lady asking about a boy she saw in a gathering and then approaches to his mother to "indent" possibility for arranging married (Personal Interview with Mrs. B, 26 November 2015).

Another kind of "arranged marriage" could be seen from an ethnographic note bellow:

In 2011, we was invited by one of Indonesian community in Sydney to attend a dinner gathering in one of Padang family. 
The menu of the dinner was Padang culinary. The gathering was part of an engagement ceremony for his Australian born girl. What make me surprise was that the male suitor was an Indonesian young huffadz, graduated from Al-Azhar University. He was invited by the community to Sydney to be an Imam sholat at Al-Hijra mosque during Ramadhan. Knowing that the young Imam was still single, the family who was from the same ethnic background with the Imam, intend to merry his daughter to him. The community was so enthusiast for the engagement, because in short time they will have an Indonesian Imam for their mosque.

Indonesian Muslims in Sydney actively keep in touch with the issues and current trend in their home country, ranging from politic, religious movement, entertainment to fashion. When we just arrived in Sydney for this research and visited one of Indonesian family permanent resident, a lady questioned us with enthusiast about Syi'ah movement which was the trending topic in Indonesian media. Her face was so anxiety indicating that, on her mind, Indonesian is vulnerable from Syiah infiltration. About the fashion, Indonesian Muslims women actively update attire style by requesting their Indonesian relatives to send current model of hijabs (Personal Interview with Mrs.Tris, a Permanent Resident from Sumatera, 25 November2015). In this case, most Indonesian family in Sydney have parabola to watch and update their information about Indonesia through Indonesian television broadcastings, including various popular sinetron (soap opera series).

\section{Segmentation and the Challenge of Trans-National Islamic Movements}

As described in chapter three, there are about 34 Indonesian Muslim communities in Sydney. The fact that they are segmented into a number of groups can be seen both as a prospect and challenge. Some groups are based on ethnicity, some are representation of Muslim organization in Indonesia, some are based on profession, and some also based on hobbies. From religious economic model theory, the segmentation is a positive point in term that Indonesian Muslims have many choices which group they want to belong. From social inclusion perspective, the availability of various Indonesian Muslim groups in Sydney from different backgrounds meaning the variety channels for promoting Indonesian cultures abroad. The more groups, therefore, the wider social resonance of Indonesian Muslim in Sydney.

Nevertheless, this is not always the case, because the variety of Indonesian Muslim communities in Sydney could also indicate that Indonesian Muslims are segmented in various groups based on their specific interest and agenda. These segmented groups are relatively difficult to be coordinated due to the fact there is no single umbrella organization for Indonesian Muslim in Australia as well as in Sydney as that also for Australian Muslims in general. The absent of an umbrella organization causes the voice of Indonesian Muslim in Sydney are relatively weak (FGD with one of Indonesian Muslim Community in Sydney, 22 November 2015). The problem even could be worse due to the fact that not all Indonesian Muslims communities are the representation of groups that are in Indonesia. There are also Indonesian Muslim communities which are affiliated to a trans-national Islamic movement, namely Hizbut Tahrir (HT).

Unlike Indonesian Muslim communities those are the representation of Muslim organization in Indonesia and those are based on ethnicity, profession or hobby which are all still fond of promoting Indonesia values and ideology, the group affiliated to the trans-national Islamic movement, the HT for example, tend to avoid their Indonesian identity and prefer promoting new kind of Islamism based on Caliphate system. The different orientation and world view from the major communities on the ideal types of Muslim society HT group want to build in Australia has led the group to militantly and actively campaign and recruit new members. This situation causes Muslim communities as an arena of contestation.

Initially many Indonesian Muslims welcomed to the idea of HT by inviting 
HT ustadz in Islamic lecture, but later on a number of communities resist the group due to its exclusivity and critical thinking to democratic political system. For this regard, segmentation and even competition and tension among Indonesian Muslim communities are difficult to be avoided. There was even an initiation to create counter group to block HT activities. One of Indonesian Muslim communities that actively held a regular meeting to counter the idea of HT is formed by some former HT members. The main reason for them to step away from HT was the unrealistic ideas of HT to be implemented in a wider society, especially for those who already have a family and have stronger social obligation in community. The ideas of HT, according to this group, are only fit for young people who still highly obsessed by idealism (Personal Interview With Ustad Wahyu, a former HT Ustad, 28 November 2015). The problematic position of HT among Indonesian community is illustrated in this following note:

During the dinner at a gathering I met an Indonesian ex-HT activist in Australia. He talked about his experience doing dakwa for more than 10 years in Australia and his involvement in the HT. He quitted from the HT after realizing that, on his opinion, HT's programs and agendas are not realistic. He said "Muslim around the world are overwhelmed by many social and economic problems, such as poverty, low of education, and social injustice, but why HT did not do direct action to solve those problems instead of only sounding the important of upholding Khilafa?" (Personal Interview with Ustad AB, 27 November 2015).

One informant from mosque $\mathrm{Al} \mathrm{Hijra} \mathrm{also}$ told me that in the past HT activist frequently conducting lecturing program in the mosque, but the content of the lecture some time create tension among the jamaah. Finally, the board of the mosque declared that mosque is not political arena; it is the place for all Muslim. After that the HT activities were limited in the Al Hijra mosque (Personal Interview with Mr. T, one of congregational board of alHijrah, 26 November 2015).
In addition to the segmentation and trans-national Islamic movement, another challenges faced by Indonesian Muslim communities in Sydney is difficulty to build mosque. As the prices of land and property in Sydney are very expensive, Indonesian Muslim communities in Sydney have limitation to collect huge amount of money. In addition to financial support, the major challenge on such issue is gaining permission from local government. The procedure and administrative permission for building mosque from zero is more difficult than transforming a worship house, a church for example, into a mosque. Mosque Al-Hijra of CIDE in Tempe, considered as the first Indonesian Masjid in Sydney was originally a church and then changed into a mosque. The Iqra' Foundation which bought a house are now still facing permission problem from the government to change it into a mosque. The legal permission for the activities of the foundation in the house is community youth Centre. Consequently, the community cannot perform Friday prayer in the Centre but they are allowed to conduct congregation for daily prayer, Qur'anic studies, and other related activities for youth and community members in general (FGD, 22 November 2015).

\section{Prospect: Agents of Moderation, Toler-} ant and Envoy of Indonesian Culture

As As already acknowledged by some expert on Islam and Indonesia, Indonesian Muslims are more tolerant to differences than their counterparts from let's say Middle Eastern or South Asian. While Middle East and South Asian are still frequently overwhelmed by bloody religious conflict, interreligious relations in Indonesia are relatively harmonious. The rich experiences on religious and ethnical diversities have led Indonesian Muslims to respect differences and fond of moderate way of Islam. Indonesia, as the most pluralistic societies in the world and in term of religion it is the largest Muslim nation in the world, is the best sample where religion (Islam) and modernity as well as democracy can coexist together. 
Nurcholis Madjid noted that Indonesia is a good example for the problem solving of interreligious tolerance (Madjid 1994, p.5577). Robert W. Hefner even accredited Islam in Indonesia is the civilized Islam, implying that there is another "uncivilized Islam" in other place of the world (Hefner 200o). A huge number of Indonesian Muslim communities in Sydney therefore have strategic position and role to promote Indonesian values of moderation and tolerance.

Beside these academic acknowledgments of Indonesian Islam, at a praxis level, some Indonesian Islamic organizations, such as Muhammadiyah and Nahdlatul Ulama, have great experiences to be mediators to solve some religious conflicts worldwide. To run a function as agents for moderation and tolerance, therefore, is actually not an easy task. It requires all Indonesian Muslim communities in Sydney to have similar ways to both Indonesian Islamic groups in presenting and practicing Islam in their daily life. They have to deal with several differences among them first to later be agents of moderation and tolerance.

To some extents, the segmentation of Indonesian Muslims in Sydney into many groups indicates that they are socially active. Indonesian Muslims in Sydney proliferate into a number of activities, meaning channels to promote moderate and tolerant model of Indonesian Muslim are available in many forms. Nevertheless, based on this study, such potential channels have not been used effectively in term of outreaching to non-Indonesian due to the fact that most of their programs are directed to internal Indonesian society. Of course, there are Indonesian communities who have tried to outreach to non-Indonesian as that have done by CIDE and Iqra' Foundation, but they are still limited to Muslim communities. For this regards, Indonesian Muslim communities in Sydney should learn from Turkish Muslim communities in Auburn, Sydney that has run various multi-religious and multicultural programs.

If all Indonesian Muslims in Sydney actively promote the moderate and tolerant model of Islam, either to non-Indonesian
Muslim communities or non-Muslim communities in general, any stigmas that Islam is religion of violence, as propagated by Western media and some anti-Muslim groups, will gradually reduce. It is therefore the duty of Indonesian Muslims, to present the beauty, harmony and peace of Islam. To do so, there is a need for Indonesian Muslim communities to have a big umbrella in order to minimize their tensions and differences. Most of Indonesian Muslim communities' members are hoping for the official representation of Indonesian government, the Indonesian consulate in Sydney, to have someone who has integrity in Islamic knowledge to be formally appointed as their official representation of Indonesian Muslims.

\section{CONCLUSION}

Indonesian Muslims who live in Australia are relatively small if we consider that we are the closer neighbor of Australia and have the biggest Muslim populations in the world. Australian Census in 2011 reported that Indonesian Muslims are in the ninth position and made up 2.6\% of total Muslims in Australia. This number can be doubled if we consider students and other illegal workers. It is difficult, of course, to count the exact numbers of Indonesian Muslims in Sydney, the most populous Muslim state across Australia. However, based on more than 35 Indonesian Muslim communities in Sydney, we can hope that Indonesian Islam, which is commonly associated with religious model of moderation and tolerance, can be well represented by those communities.

Most Indonesian Muslim communities in Sydney are in the form of kelompok pengajian (Islamic study group), which is commonly based on ethnicity, regionalism (province and regency), religious affiliation with Indonesian Islamic groups, such as Muhammadiyah and Nahdlatululama, or occupations. Interestingly, in most cases, members of one Indonesian Muslim community also become active members of other Indonesian Muslim communities. For example, many informants of this research are active members of Iqra' Foundation, which formerly being associated with 
Tarbiyah movement, but they also involved in other Indonesian Muslim communities, such as Salsabila, AshabulKahfi, and al-Hijrah. In general, their involvements in several Indonesian Muslim communities are based on their different needs, such as for their children's education, regionalism, and other interests. This phenomenon can be seen as an evident of how Islamic social capital, in term of Farooqi's concept, is utilized in supporting the needs of Indonesian Muslim communities in Sydney. Networking of several Muslim communities opens a greater possibility for their members to optimize and take some advantages for other communities' resources.

Most Indonesian Muslim communities built their relationships with Islamic organizations in Indonesia through personal relations. Usually, most Indonesian Muslim communities have strong or weak relationships with Islamic organizations in Indonesia depend on their leaders. In most cases, this relationship is clearly indicated from regular ustadz or public figure they invited to various events, especially during the month of Ramadhan. However, even though the leader of community has a significant influence to determine who will be invited for certain events, the members of community has a natural procedure to reject some invited speakers through their absent in those events. In the case of al-Hijrah mosque, for example, many members have succeeded in rejecting several ustadz who are indicated as members of certain radical groups through the boycott process, which eventually be responded by the board to ban some ustadz by declaring that mosque must be free from political interest. Besides, it is very common among the Indonesian Muslim communities to cooperate in inviting certain speakers from Indonesia and ask them to deliver speeches in each community. Therefore, most Indonesian Muslim communities in Sydney has a strong relationship except for some groups that are indicated of having connection with trans-national Islamic groups that tend to be an exclusive group.

The main problem of Indonesian Mus- lim communities in Sydney is an ambiguous identity, laziness integration, and dream to home country. No matter how long they have been in Sydney, they still fond of going home to Indonesia someday. It is fair to say that Indonesian Muslim diaspora in Sydney just see Australia as the land for making money. For this regard, their inclusion to Australian community is just being "Indonesian Muslim in Australia" and it seems hard for them to be "Australian Muslim" in the case of those who already changed their nationality. This kind of diaspora attitude differs from Muslims Diasporas from the Middle East and South Asia countries who are mostly ready to be fully Australian Muslim.

Originally, Indonesian Muslim diaspora in Sydney had created their various communities just for media of silaturami, meet and greet, family gathering with religious niches. Nothing is about ideology. Later on, when there was a small group Muslim activists promoting trans-national Islamism with certain ideological agenda, the major silaturahmi groups then reconstruct their home ideological worldview in respond to the trans-national group as their internal defense mechanism. Therefore, in nature, most Indonesian Muslim communities put their emphasis to develop their community based on social needs and try to avoid political idea of Islamism. In this case, the Indonesian government, through the Indonesian Consulate in Sydney, has great resources to promote moderate and tolerant views of Indonesian Islam to other Muslim communities, as well as to Western media.

In optimizing resources of Indonesian Muslim communities in Sydney to envoy Indonesian cultures and policies, it is necessary for Indonesian government to have a person with integrated knowledge on Islamic Studies who are working officially under the Indonesian consulate in Sydney. This position is so crucial because Indonesian Muslim communities need a patron, both to unify and soften the differences among them, as well as to help them link with a wider communities in Australia. 


\section{REFERENCES}

Akbarzadeh, S., \& Saeed, A., 2001. Muslim communities in Australia. UNSW Press, Sydney.

Akbarzadeh, S., \& Yasmeen, S., 2005. Islam and the West : reflections from Australia. University of New South Wales Press, Sydney.

Bourdieu, J., 1986. Forms of Social Capital. In J. Richardson (ed.), Handbook of Theory and Research for the Sociology of Education. Greenwood Press.

Burnley, I., 2001. The Impact of Immigration on Australia: A Demographic Approach. Oxford University Press, South Melbourne.

Collins, J., Noble, G., Poynting, S., \& Tabar, P., 2000. Kebabs, Kids, Cops \& Crime: Youth, Ethnicity $\mathcal{E}$ Crime. Pluto, Sydney.

Dragojlovic, A., 2012. Materiality, loss and redemptive hope in the Indonesian leftist diaspora. Indonesia and the Malay World, 40(117), pp.16o-174.

Dreher, T., Dreher, T., \& Ho, C., 2009. Beyond the hijab debates : new conversations on gender, race and religion (New ed.). Cambridge Scholars, Newcastle.

Farooqi, A.H., 2006. Islamic Social Capital and Networking. Illumanomics, 22, pp.113-125.

French, D.C., Eisenberg, N., Vaughan, J., Purwono, U. and Suryanti, T.A., 2008. Religious involvement and the social competence and adjustment of Indonesian Muslim adolescents. Developmental psychology, 44(2), p.597.

Ganter, R., Martinez, J., \& Lee, G.M., 2006. Mixed relations : Asian-Aboriginal contact in North Australia. University of Western Australia Press, Crawley, W.A.

Giles, B., 2010. Somali Narrative on Islam, Education and Perception of Difference. In S. Yasmeen (Ed.), Muslim in Australia, The Dynamic of Exclusion and Inclusion. Melbourne University Press, Carlton.

Hage, G., (Ed.) 2002. Arab-Australian Today: Citizenship and Belonging. Melbourne University Press, Melbourne.

Hassan, R., 2015. Australian Muslims: A Demographic, Social and Economic Profile of Muslims in Australia. Adelaide: International Centre for Muslim and non-Muslim Understanding, University of South Australia.

Hefner, R.W., 20oo. Civil Islam: Muslims and democratization in Indonesia. Princeton University Press, Princeton, N.J.

Heiss, J. and Slama, M., 2010. Genealogical Avenues, Long-Distance Flows and Social Hierarchy: Hadramī Migrants in the Indonesian Diaspora. Anthropology of the Middle East, 5(1), pp.34-52.

Heiss, J. and Slama, M., 2010. Genealogical Avenues,
Long-Distance Flows and Social Hierarchy: Hadramī Migrants in the Indonesian Diaspora. Anthropology of the Middle East, 5(1), pp.34-52.

Howell, J.D., 2005. Muslims, the new age and marginal religions in Indonesia: Changing meanings of religious pluralism. Social Compass, 52(4), pp.473-493.

Kabir, N., 2004. Muslim in Australia: immigration, race relations and cultural history. Kegan Paul, London.

Madjid, N., 1994. Islamic Roots of Modern Pluralism: Indonesian Experiences. Studia Islamika, 1(April-June), pp.55-77.

Meuleman, J. H., 2002. Islam in the era of globalization : Muslim attitudes towards modernity and identity. RoutledgeCurzon, London, NY.

Parekh, B., 2005. Europe, liberalism, and the Muslim Question. In T. Madood, A. Triandafyllidou \& Zapata-Barrero (Eds.), Multiculturalism, Muslims and citizenship: a European Approach . Routledge, London.

Poynting, S. and Mason, V., 2006. “Tolerance, freedom, justice and peace"?: Britain, Australia and antiMuslim racism since 11 September 2001. Journal of intercultural studies, 27(4), pp.365-391.

Putnam, R.D., 200o. Bowling alone : the collapse and revival of American community. Simon \& Schuster, New York.

Putnam, R.D., 2007. E Pluribus Unum: Diversity and Community in the Twenty First Century. Scandinavian Political Studies, 30, pp.137-174.

Roy, O., 2004. Globalised Islam : the search for a new Ummah. Hurst, London.

Saeed, A., 2003. Islam in Australia. Allen \& Unwin, Crows Nest, NSW.

Slama, M., 2011. Translocal Networks and Globalisation within Indonesia: Exploring the Hadhrami Diaspora from the Archipelago's North-East. Asian Journal of Social Science, 39(2), pp.238257.

Stephenson, P., 2010. Islam dreaming: Indigenous Muslims in Australia. UNSW Press, Sydney.

Turner, B.S., 2013. Islam, Diaspora and Multiculturalism. In B. S. Turner \& K. M. Nasir (Eds.), The Sociology of Islam: Collected Essay of Bryan S. Turner. Surrey \& Burlington, Ashgate.

Underabi, H., 2014. Mosques in Sydney and New South Wales. University of Western Sydney, and Charles Sturt University, ISRA, Sydney.

Winarnita, M. and Herriman, N., 2012. CARING AND FAMILY: Marriage Migration to the Malay Muslim community of Home Island (Cocos Keeling Islands). Indonesia and the Malay World, 4o(118), pp.372-387. 